\title{
SURFACING ACTIVITY AND FOOD UTILISATION IN THE OBLIGATORY AIR-BREATHING FISH OPHIOCEPHALUS STRIATUS AS A FUNCTION OF BODY WEIGHT*
}

\section{E. VIVEKANANDAN**}

\author{
School of Biological Sciences, Madurai University, MADURAI 625021, India \\ ** Present address: Central Marine Fisheries Research Institute, Post Bag No. 1912, COCHIN-6820I8, India.
}

Received January 9, 1977

Keywords: Surfacing activity, food conversion, metabolism, fed and starved series, body weight

\begin{abstract}
Reared in cylindrical aquaria containing different depths of water $(2.5$ to $70 \mathrm{~cm})$ the obligatory air-breathing fish Ophiocephalus striatus, belonging to different weight classes (0.1, 0.75, 10, 20 and $4 \mathrm{I} \mathrm{g}$ ), was forced to swim vertically a longer or shorter distance per surfacing. Surfacing frequency was a depth-dependent activity in individuals weighing less than $20 \mathrm{~g}$ in all weight classes, the frequency was nearly 2 times more in the series fed ad libitum on fish muscle, than in the one where the fish were starved. Owing to the sustained surfacing activity and the consequent fatigue, the test individuals 'hung' to the surface for a definite period. Neither frequency nor duration of hanging was depth-dependent. Mean hanging durations for the feeding series were I.I, 3.8, 5.9, 7.9 and $8.8 \mathrm{hr} /$ day in the $0.1,0.75,10,20$ and $4 \mathrm{I} g$ weight classes, respectively; the corresponding values for the starving series were I.3, $\mathrm{I} 5.0, \mathrm{I} 3.0, \mathrm{I} 2.7$ and $\mathrm{I} 2.8 \mathrm{hr} /$ day. The distance swum by the feeding fish increased from 57 to $68 \mathrm{I} \mathrm{m} /$ day and from 6I to $507 \mathrm{~m} /$ day in the 0.1 and $4 \mathrm{I} \mathrm{g}$ individuals exposed to the minimum and maximum aquarium depths. Feeding rate, which was a depthdependent activity, decreased from 280 to $\mathrm{I} I 3 \mathrm{~g} \mathrm{cal} / \mathrm{g}$ live fish day with increasing weight. Rate and efficiency of conversion also decreased with increasing body weight; in larger fish conversion was dependent on volume rather than on depth of the aquarium. $\mathrm{O}_{2}$ uptake of feeding fish was about 6 times higher than the starving ones of the tested weight classes at different aquarium depths.

* This paper is part of a thesis submitted by the author (from A.P.A. College, PALNI) to Madurai University in partial fulfillment of the requirement of the $\mathrm{Ph}$. D. degree. Contribution No, I2 under a research scheme granted to Dr. T. J. Pandian by the UGC (New Delhi). The author is grateful to Dr. T. J. Pandian for valuable guidance, financial support and encouragements.
\end{abstract}

Dr. W. Junk b.v. Publishers - The Hague, The Netherlands

\section{Introduction}

There are many publications on the effects of environmental factors like temperature (e.g. Vivekanandan \& Pandian, 1977) and light (e.g. De Roth, 1973) on surfacing activity of air-breathing fishes; but these papers do not consider the possible effect of the endogenous factors such as body weight of the fish on surfacing. Of the hundreds of publications available on food utilisation (e.g. Ricker, I946; Brown, I957; Paloheimo \& Dickie, I966a; b; Warren \& Davis, 1967; Weatherley, 1972), none discusses the combined effects of surfacing and body weight on food utilisation. The present paper deals with the effects of body weight on the surfacing activity and food utilisation in the obligatory air-breathing tropical fish Ophiocephaius striatus.

\section{Material and methods}

By rearing Ophiocephalus striatus in cylindrical aquaria containing different depths of water, it is possible to force the fish to swim vertically a longer or shorter distance per surfacing to exchange atmospheric air. To study the interaction of body weight and aquarium depth on the surfacing activity and food utilisation, $O$. striatus belonging to different weight classes (O. I, 0.75, IO, 20 and $4 \mathrm{I} \mathrm{g}$ ) were exposed to 4 or 5 different aquarium (cylindrical) depths, so chosen that the test fish swam a minimum of 9 times 

too low to elicit significant difference in the surfacing frequency, i.e. whereas the $0.75 \mathrm{~g}$ individual swam nearly $\mathrm{I} 8$ times its body length/surfacing, the larger fishes could swim only 9 or 12 times their body lengths/surfacing in the deepest aquarium $(70 \mathrm{~cm}$; see Table I). To test whether this argument is correct, the data obtained on the surfacing frequency were plotted in the lower left panel of Figure 1 as a function of the number of its body length (L) each weight class swam per surfacing. The trends obtained for the surfacing frequency of the 0.75 and $10 \mathrm{~g}$ weight classes increased as a function of body lengths (L) travelled (expressed in respective body length of the test individual/surfacing), but those obtained for the 20 and 4I $\mathrm{g}$ were almost horizontal, indicating that the surfacing frequency in these larger weight classes would not increase, if they are given opportunity to travel more body lengths (L)/surfacing in aquaria deeper than $70 \mathrm{~cm}$. Incidentally, the flat trends obtained for the fry (O.I g) reveals that the surfacing is not depth-dependent in this weight class (Fig. I; left panel) (see also Vivekanandan, I977b).

However, the level of surfacing frequency is dependent on the body weight of the test individuals. The frequency decreased from the highest value of I,879 times/day (Table II) for the $0.75 \mathrm{~g}$ individual exposed to the $40 \mathrm{~cm}$ aquarium depth to 576 times/day in the fish weighing $4 \mathrm{I}$ g reared at a depth of $70 \mathrm{~cm}$ (Table VI).

The trends obtained for the surfacing frequency in the starving series either as a function of aquarium depth or body length (the distance swum/surfacing $=\mathrm{L}$ ) for the different weight classes are also shown in Figure I (right panels). All the trends are flat indicating that the surfacing frequency is not a depth-dependent behaviour in the tested weight classes. With increasing body weight, however, the frequency level progressively decreased from I, 2 I 2 surfacings/day in the O. I $g$ weight class (the mean of means obtained for the different depth groups) to 277 surfacings/day in the largest tested individual (41 g).

The level of surfacing activity in comparable weight classes was around 2 to 3 times higher for the feeding series than the starving series. For instance, the feeding series of the $0.75 \mathrm{~g}$ weight class surfaced, on an average, I, 560 times/day in aquaria containing different depths of water. But the starving individuals surfaced only 468 times/day. Comparable values for the $4 \mathrm{I} \mathrm{g}$ weight class are around 534 times/day for the feeding series, and around 277 times/day for the starving series.

\section{Hanging frequency}

Hanging frequency of $O$. striatus fluctuated around 320 

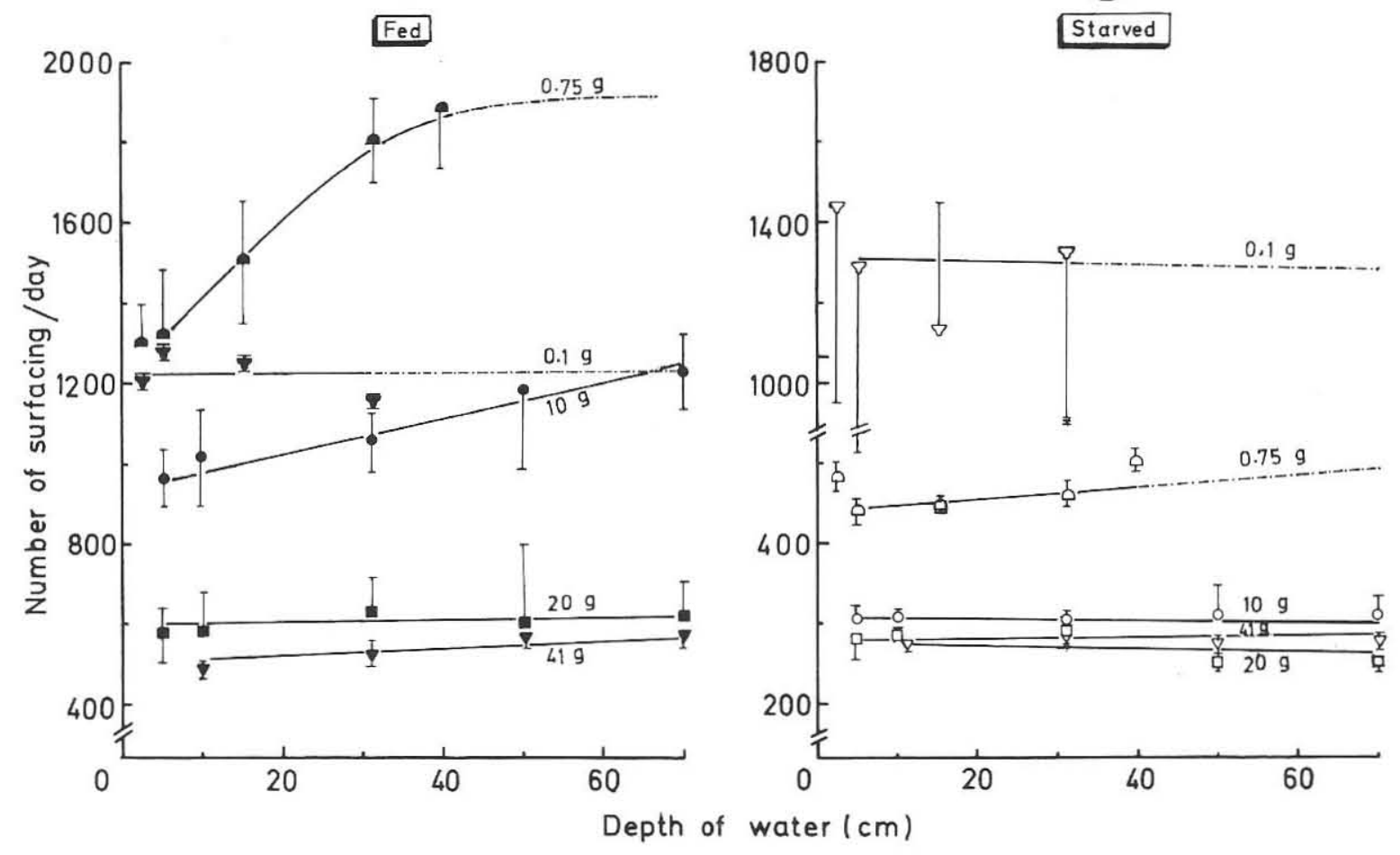

(a)

(b)

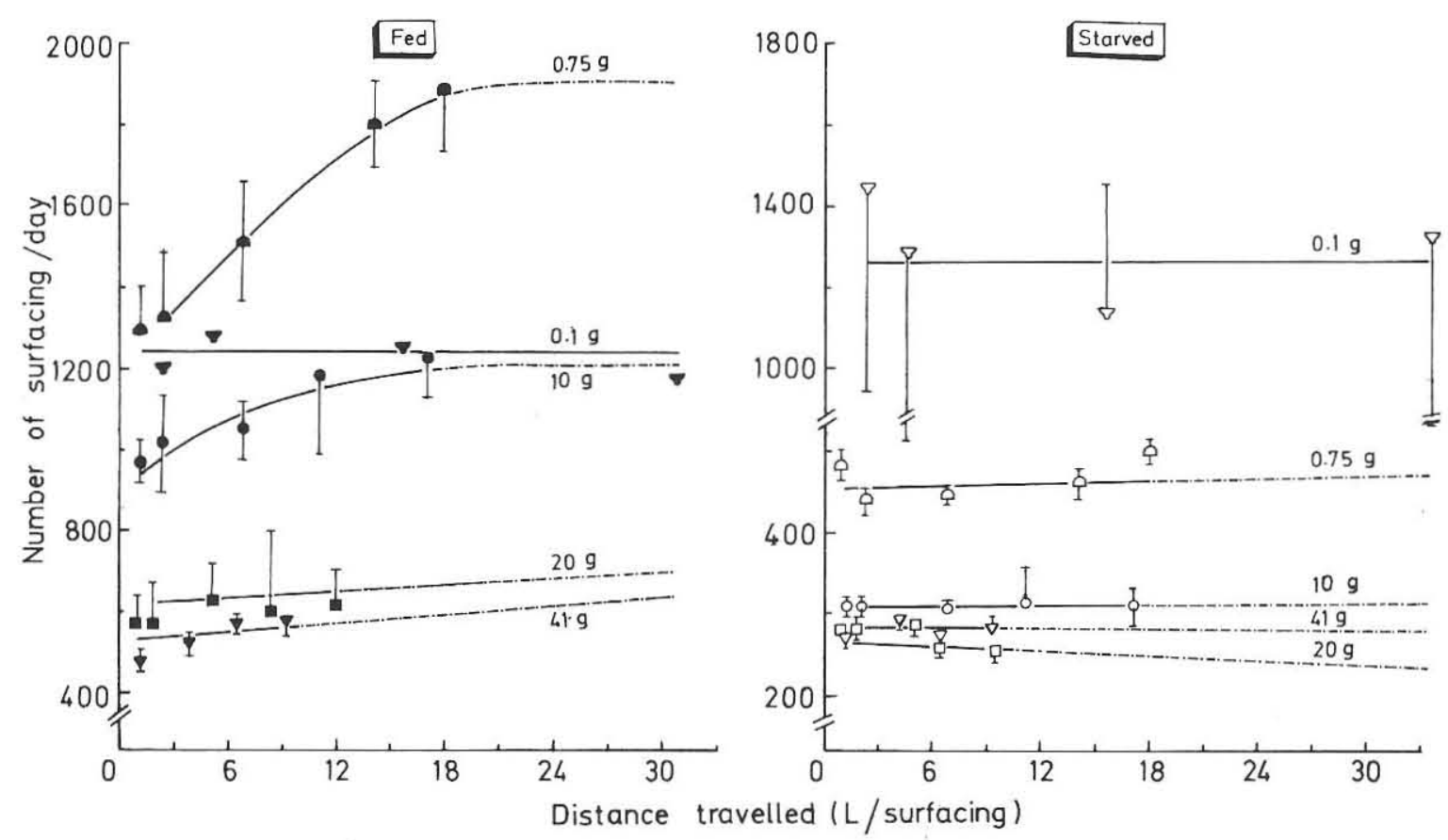

Fig. 1. Relation between aquarium depth and surfacing frequency in Ophiocephalus striatus (upper panels); in lower panels, surfacing frequency is plotted as a function of number of body lengths (L) of the respective weight classes of the fish swum per surfacing. Each value represents the average $( \pm \mathrm{SD})$ performance of 3 to 6 individuals at $27^{\circ} \mathrm{C}$. 
times/day in both the starving and feeding individuals of o. I g body weight, and it did not vary significantly as a function of either aquarium depth or nutritional status of the fish (fed or starved). The larger individuals also showed flat trends; hence, aquarium depth appears not to elicit any significant effect on hanging frequency in different weight classes of either series. With increasing body weight, there was a progressive decrease in the level of hanging frequency (Fig. 2a \& b; left panel). For instance, the level of frequency was around I20 times/day for the feeding series but below 90 times/day for the starving series of $\mathrm{Io} g$ fish (Table IV); the corresponding values for 4I $\mathrm{g}$ fish were 80 and 50 times/day, respectively (Table VI). Therefore, hanging frequency is a size-dependent activity.

\section{Hanging duration}

Hanging duration is also not a depth-dependent behaviour in the feeding (Fig. 2a; middle panel) and starving (Fig. 2b; middle panel) O. striatus of different weight classes. This conclusion is supported by the flat trends obtained for the hanging duration as a function of aquarium depth.

The hanging duration is, however, significantly influenced by the body weight of $O$. striatus. At different tested depths, hanging duration was $8.8 \mathrm{hr} /$ day for the largest feeding fish $(4 \mathrm{I} \mathrm{g})$; the corresponding values were $7.9,5.9,3.8$ and I.I hr/day for the $20,10,0.75$ and $0.1 \mathrm{~g}$ individuals, respectively, i.e. with increasing body weight, the hanging duration is significantly prolonged (e.g. feeding series of $0.75 \mathrm{~g}$ vs $4 \mathrm{I} \mathrm{g}$ at $3 \mathrm{I} \mathrm{cm}$ water depth; $\mathrm{t}=\mathrm{I} 6.434$, $\mathrm{P}<0.001)$.

In the starving series, the hanging duration remained remarkably equal around $\mathrm{I} 2.8 \mathrm{hr} /$ day in the different weight classes ( $\mathrm{IO}, 2 \mathrm{O}$ and $4 \mathrm{I} \mathrm{g}$ ) at all the tested aquarium depths. However, individuals weighing $0.75 \mathrm{~g}$ hung for a longer duration (around $\mathrm{I} 5 \mathrm{hr} /$ day) at different aquarium depths, but the smallest tested fry (O.I g) hung for only I.7 $\mathrm{hr} /$ day. Therefore, the duration of hanging is neither a depth-dependent behaviour nor a size-dependent activity in the starving fish weighing less than $\mathrm{rog}$.

\section{Swimming activity}

In all the tested weight classes, the distance swum by an individual due to the surfacing activity increased steeply with increasing depth of the water in the aquarium (Fig. 2a \& b; right panel). Among the feeding series, individuals weighing less than Io $\mathrm{g}$ swam proportionately longer distances in aquaria of increasing depths; whereas, 

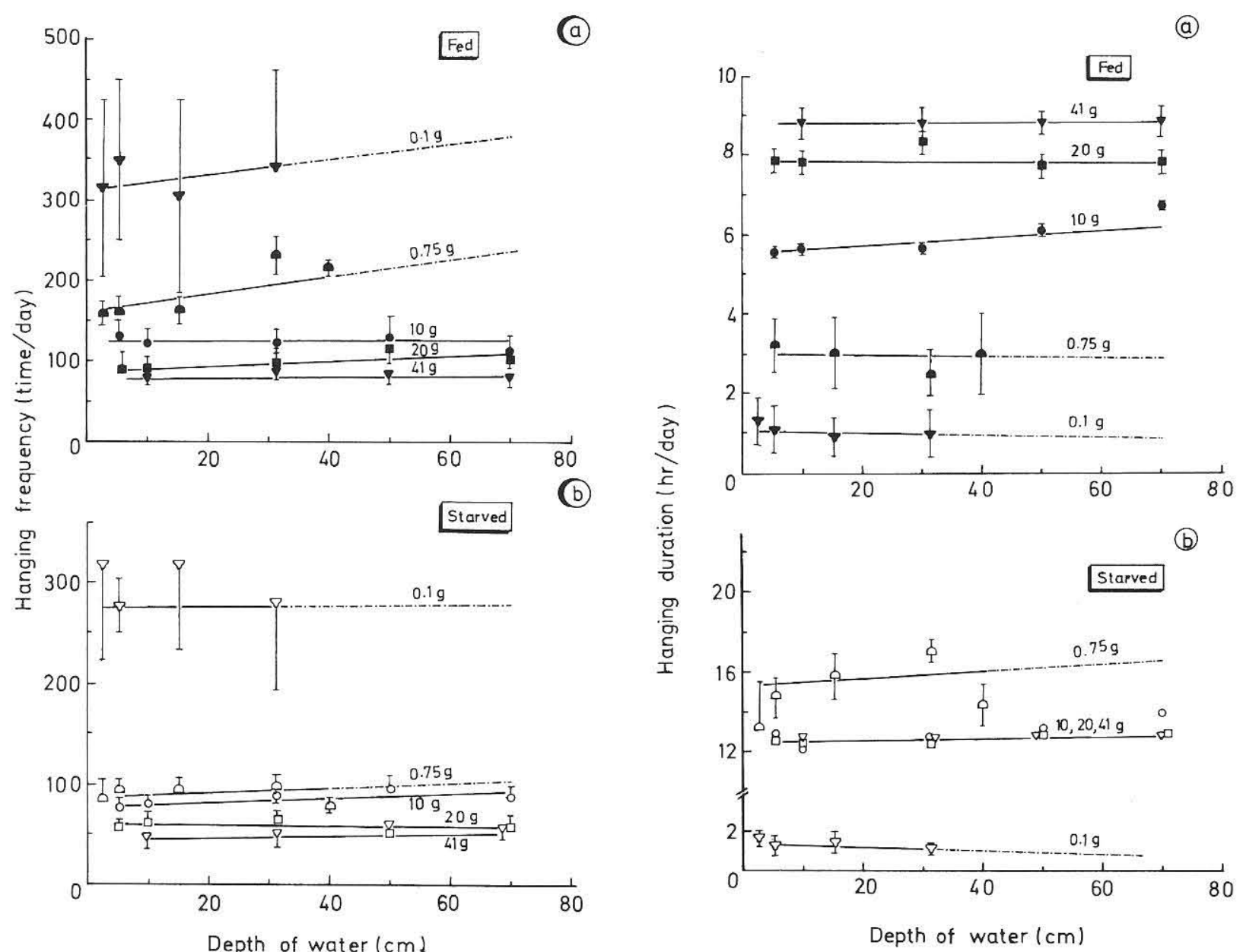

Fig. 2. Relations between body weight and hanging frequency (left panel), hanging duration (middle panel), and distance travelled (right panel) of the fed and starved Ophiocephalus striatus reared in different aquarium depths. Each value represents the average $( \pm \mathrm{SD})$ performance of 3 to 6 individuals. The dotted line in the right panel (fed group) represents the theoretical trend for proportionate increase in the distance travelled by different weight classes exposed to increasing aquarium depths.

those weighing 10,20 and $4 \mathrm{I} g$ body weight swam increasingly longer distance per se. However, the increase in the swimming distance is less proportionate to the increasing depth of their aquaria. The former weight classes increased the distance travelled in the deeper aquaria by the frequent surfacing (Fig. I; left panels) as well as by the brief hanging duration (Fig. 2a; middle panel). The latter weight classes, which travelled less proportionately, increased the distance swum in the deeper aquaria, by hanging to the surface for longer durations (Fig. 2a; middle panel) but not by changing the surfacing frequency

Fig. 2. Middle panel.

(Fig. I; left panels). Therefore, the larger individuals in the deeper aquaria tend to save energy cost of swimming to the surface by resorting to hanging to the surface for a longer period. It may be recalled that the starving fish $(0.75 \mathrm{~g})$ resorted to the same adaptive behaviour, when exposed to deeper aquaria.

Starving individuals of $0.1 \mathrm{~g}$ increased the distance travelled from $67 \mathrm{~m} /$ day in the shallowest aquarium $(2.5$ $\mathrm{cm}$; Table III) to $784 \mathrm{~m} /$ day in the deepest aquarium (3I $\mathrm{cm}$ depth). These values are comparable to those obtained for the feeding individuals of the same weight class ( 57 and $68 \mathrm{I} \mathrm{m} /$ day). Apparently, O. striatus fry (0.1 g) is not yet ontogenetically ready to gear the metabolism and the associated surfacing (see Vivekanandan, 1977b), hanging and swimming activities to lower levels, so that the energy cost of living could be reduced. Such an adap- 


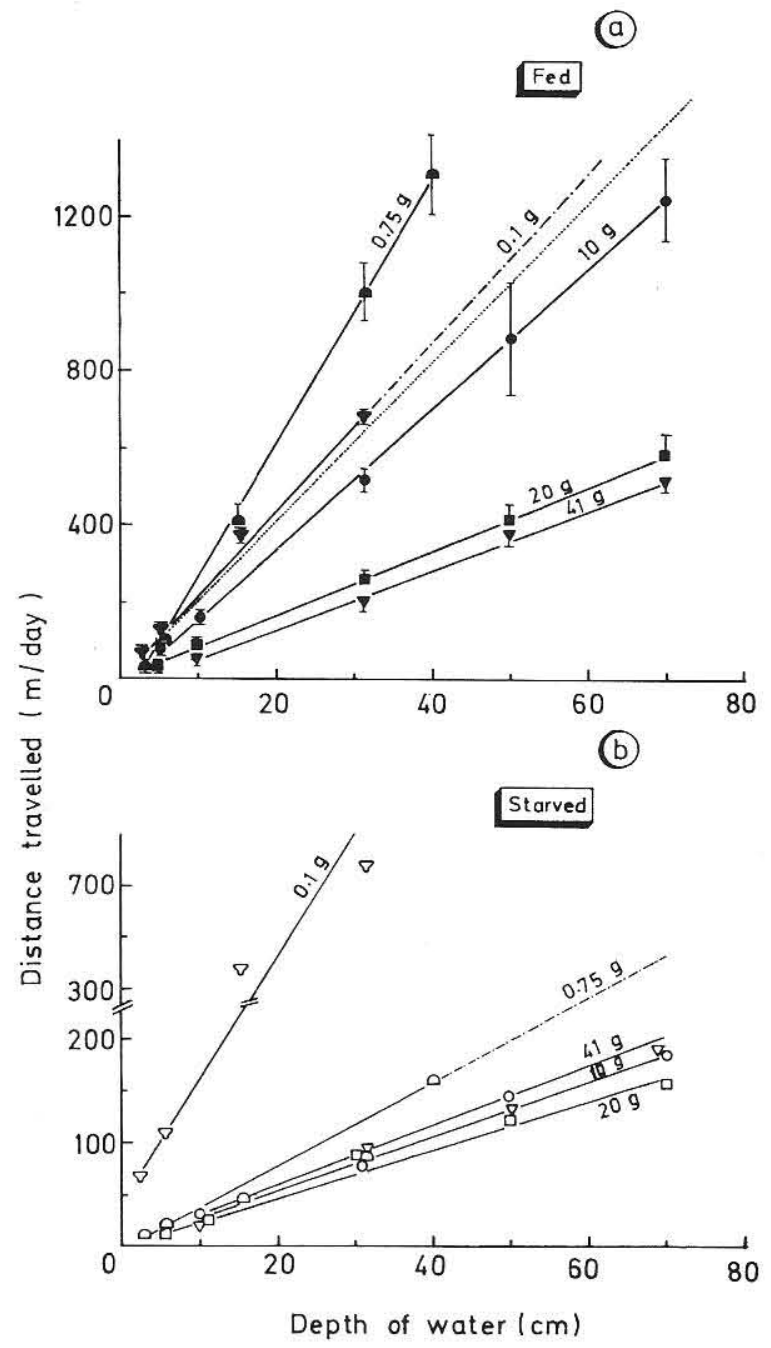

Fig. 2. Right panel.

tive gearing mechanism becomes immediately apparent, when the individuals weighing more than $0.75 \mathrm{~g}$ are subjected to starvation; the fact that the larger starving individuals swam more or less equal distance at any one tested depth (Fig. 2b; right panel) supports the abovementioned conclusion. The gearing mechanisms available to the larger starving individuals are: $\mathrm{x}$. to reduce the surfacing frequency and/or 2. to increase the hanging duration. All larger weight classes considerably decreased the surfacing frequency (Fig. I; left panels) and prolonged the hanging duration (Fig. 2b; middle panel). However, they had to swim a longer distance, when exposed to deeper aquaria (Fig. 2b; right panel).

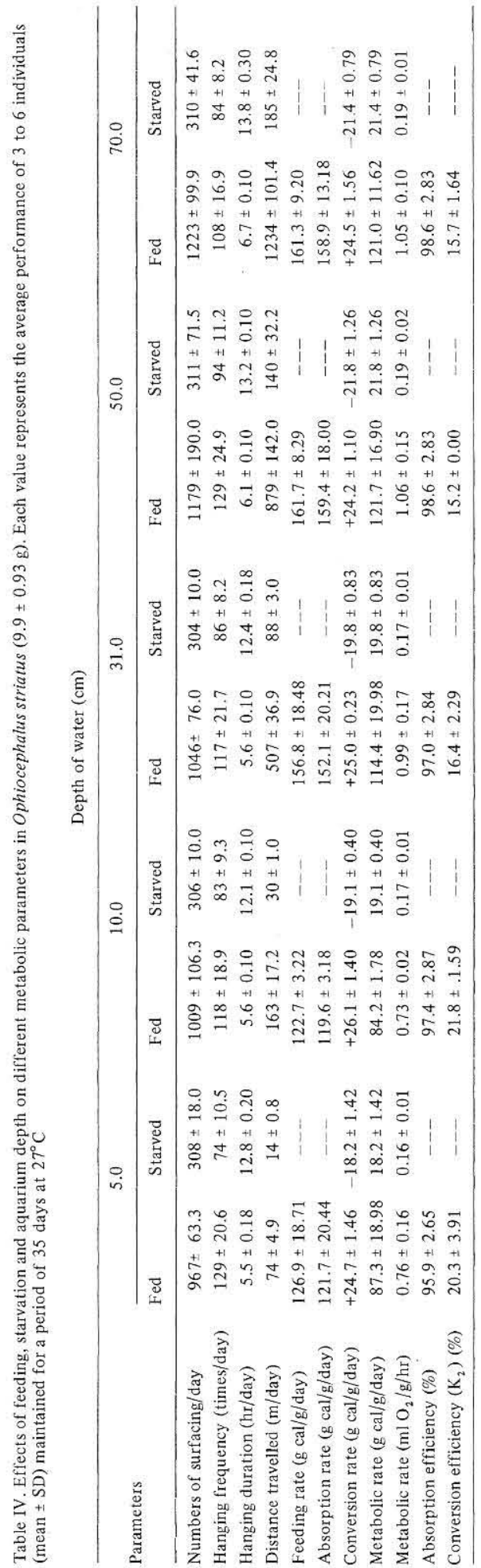




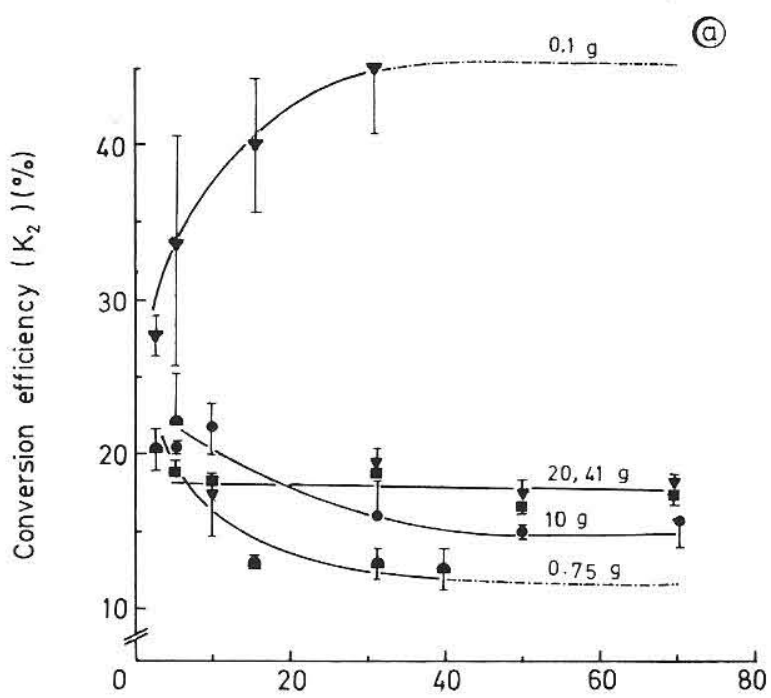

From the data presented in Tables II to VI, the following inferences can be made: $\mathrm{I}$. Feeding rate is significantly increased from the shallowest aquarium upto the peak level observed in the individuals of different weight classes exposed to an aquarium containing $3 \mathrm{I} \mathrm{cm}$ depth of water, and levels off with further increase in the depth of the aquarium. The observed increase as a function of the aquarium depth becomes steeper and steeper, as the body weight is smaller and smaller (Fig. 3b; left panel), 2. The level of feeding rate is over $260 \mathrm{~g} \mathrm{cal} / \mathrm{g}$ live fish/day in the youngest tested individual and it steadily decreased to less than $120 \mathrm{~g} \mathrm{cal} / \mathrm{g} /$ day in the largest tested fish, and 3 . If the values obtained for the feeding rate are plotted as a function of body weight, a curvilinear trend, similar to that reported for $O$. striatus by Pandian ( 1967 ) who studied food utilisation in I to I $24 \mathrm{~g}$ weight classes, was obtained. Therefore, feeding rate is not only a depth (upto $30 \mathrm{~cm}$ )dependent but also a body weight-dependent activity.

\section{Absorption}

Absorption efficiency values obtained for different weight classes of $O$. striatus ranged from $9 \mathrm{I} .3$ to $98.6 \%$ and averaged to $96 . \mathrm{I} \%$. Hence, body weight did not appreciably alter absorption efficiency. Pandian ( 1967) also reported that the absorption efficiency (97\%) of $O$. striatus did not vary among different weight classes (see also Gerking, I955, I971; Menzel, I960).

As the efficiency remained more or less equal, the trend obtained for absorption rate as a function of depth or body weight was almost parallel to the respective one obtained for feeding rate against depth or body weight.

\section{Conversion efficiency}

The values obtained for the efficiency ranged from $13 \%$ for the $0.75 \mathrm{~g}$ individual in the deepest aquarium $(40 \mathrm{~cm})$ to $45 \%$ for the o. $\mathrm{I} g$ individual in the $3 \mathrm{I} \mathrm{cm}$ deep aquarium (Fig. 3a; left panel). The highest efficiency of $44 \%$ was reported by Pandian (1967) for $O$. striatus fed on the prawn Metapenaeus monoceros. The efficiency in the present study I. increased from about $28 \%$ for the o. I $g$ weight class at $2.5 \mathrm{~cm}$ to $45 \%$ at $31 \mathrm{~cm}$ depth, 2 . decreased from about $20 \%$ in the shallowest aquarium $(2.5$ or $5.0 \mathrm{~cm}$ depth) to 12.6 or $15.7 \%$ in the deepest aquaria ( 40 or 70 $\mathrm{cm}$ ) for the weight class 0.75 or $\mathrm{IO} \mathrm{g}$, and 3 . remained more or less around $18 \%$ in the larger weight classes (20 and $4 \mathrm{I} \mathrm{g}$ ) at all tested depths. The $0 . \mathrm{I} \mathrm{g}$ weight class con-

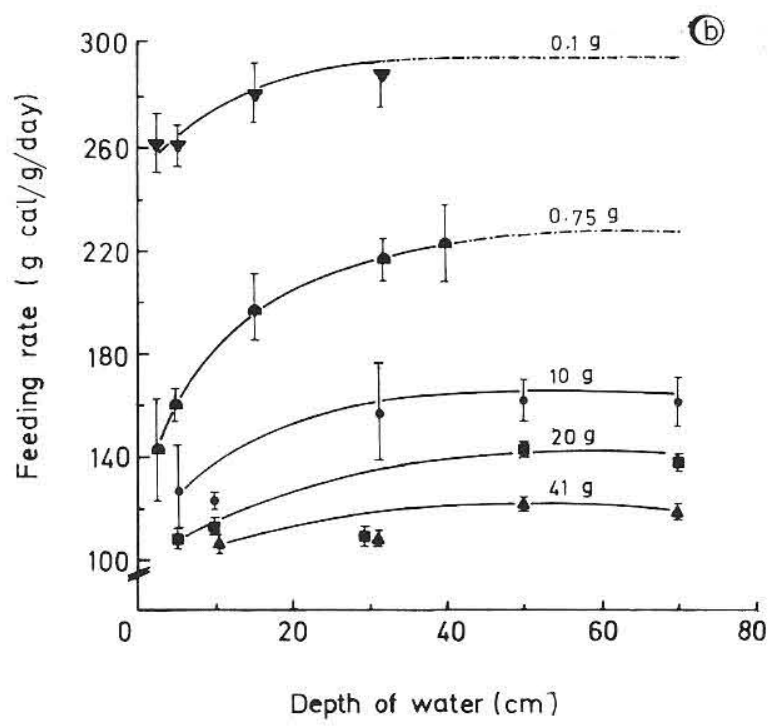

Fig. 3. Relations between body weight and feeding rate, conversion efficiency (left panel), conversion rate (middle panel) and metabolic rate (right panel) of Ophiocephalus striatus reared in different aquarium depths. Each value represents the average $( \pm \mathrm{SD})$ performance of 3 to 6 individuals.

sumed significantly more food in deeper aquaria (Fig. 3b; left panel), surfaced equal number of times (around I 200 times/day) as those in shallower aquaria, and consumed significantly less food. The extra food energy consumed in deeper aquaria is profitably converted with the highest efficiency; the intermediary weight classes ( 0.75 and $\mathrm{IO} g$ ) did consume significantly more food (upto $3 \mathrm{I} \mathrm{cm}$ depth), but remained poor convertors, as they dissipated the food 


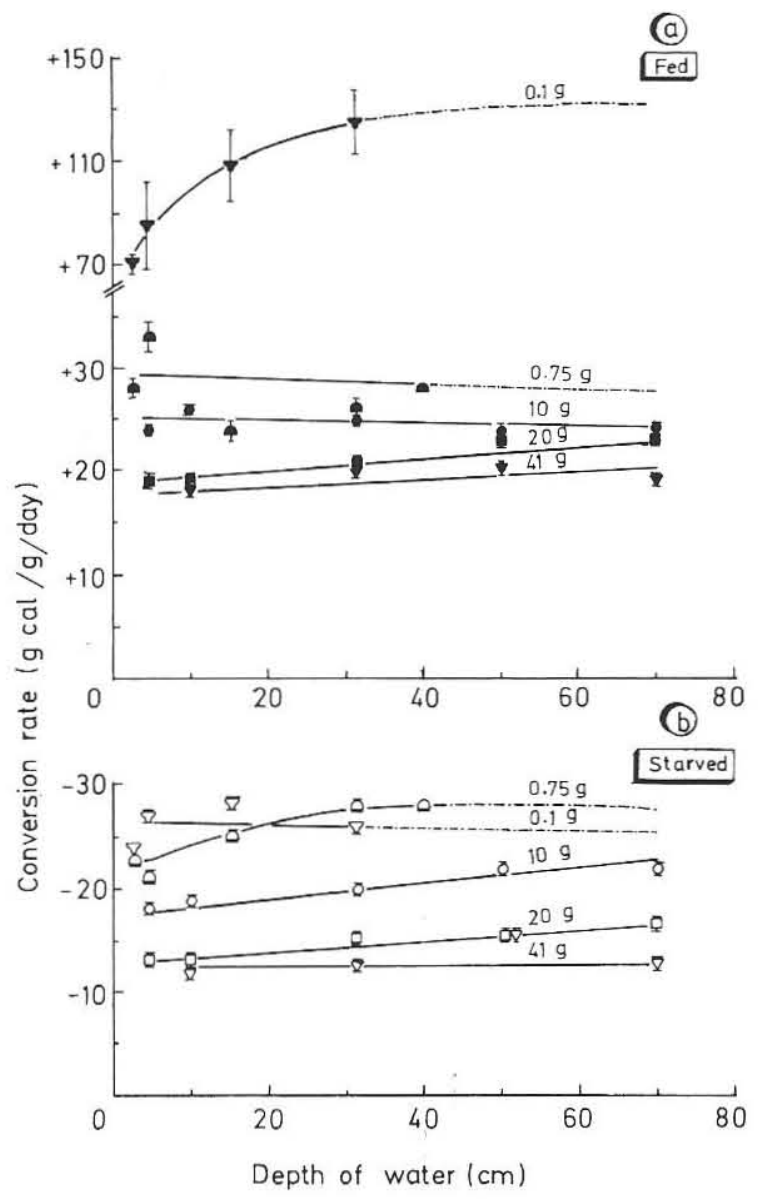

Fig. 3. Middle panel.

energy in deeper aquaria by increasing the surfacing frequency and swimming distance. Conversely, the larger weight classes consumed just significantly more food, but they adjusted the surfacing frequency and swimming activity in such a way, that they maintained the efficiency of food conversion at about $18 \%$, irrespective of the changes in aquarium depth.

\section{Conversion rate}

The trends obtained for conversion rate vs aquarium depth reflect the conclusions made in the previous section. Notable exceptions are: $I$. The level of the rate decreases in the following order: O. I $<0.75<$ IO $<20<4$ I $\mathrm{g}$, whereas the order for conversion efficiency was O.I $<$ $4 \mathrm{I}<20<\mathrm{IO}_{0}<0.75$, and 2 . The rate in the larger weight classes increased from about $\mathrm{I} 8 \mathrm{~g} \mathrm{cal} / \mathrm{g}$ live fish/day in the shallowest aquarium (Fig. 3a; middle panel) to about 2 I (a)

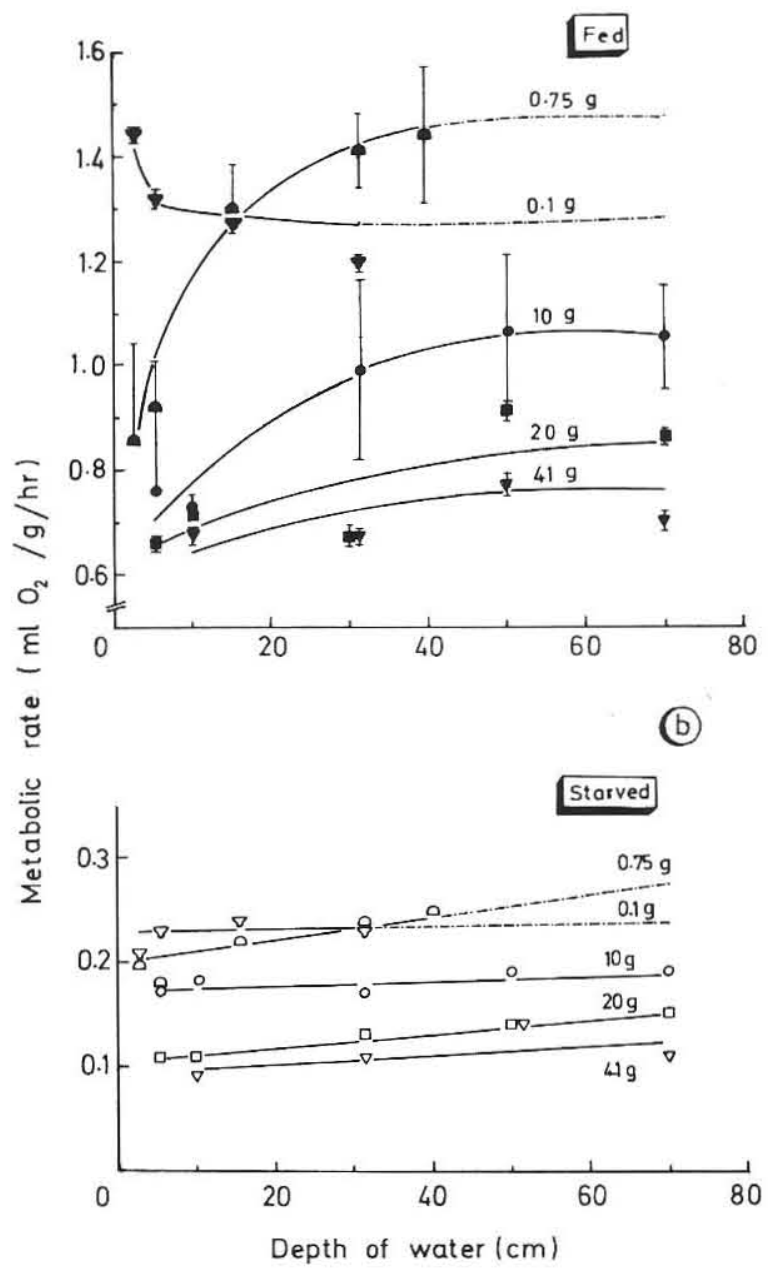

Fig. 3. Right panel.

$\mathrm{g} \mathrm{cal} / \mathrm{g} /$ day in the deepest aquarium. Though the increase is not appreciable, the rate steadily increased with increasing depth of aquarium. Moreover, this observation is remarkable in that at the deepest aquarium $(70 \mathrm{~cm})$, the fish consumed less food than in an aquarium of 50 $\mathrm{cm}$ depth (Tables IV, V, VI). Bhaskaran (unpublished) and Ponniah (unpublished), who studied the effect of volume of water (keeping the depth of water equal), showed that the air-breathing fishes Anabas scandens and Macropodus cupanus tend to show higher efficiency in aquaria containing larger volumes of water. In the present study, larger weight classes of $O$. striatus in the deepest aquarium $(70 \mathrm{~cm})$ enjoyed 12.6 to 28.01 of water as against 9.0 to 20.01 in the $50 \mathrm{~cm}$ deep aquarium. Like $A$. scandens and $M$. cupanus, the larger weight classes of $O$. 

Table V. Effects of feeding, starvation and aquarium depth on different metabolic parameters in Ophiocephalus striatus (19.8 $\pm 1.05 \mathrm{~g}$ ). Each value represents the average performance of 3 to 6 individuals
maintained for a period of 35 days at $27^{\circ} \mathrm{C}$

Depth of water $(\mathrm{cm})$

\begin{tabular}{|c|c|c|c|c|c|c|c|c|c|c|}
\hline \multirow{2}{*}{ Parameters } & \multicolumn{2}{|r|}{5} & \multicolumn{2}{|r|}{10} & \multicolumn{2}{|r|}{31} & \multicolumn{2}{|r|}{50} & \multicolumn{2}{|r|}{70} \\
\hline & Fed & Starved & Fed & Starved & Fed & Starved & Fed & Starved & Fed & Starved \\
\hline Number of surfacing/day & $574 \pm 27.6$ & $281 \pm 49.1$ & $574 \pm 28.8$ & $283 \pm 15.0$ & $624 \pm 36.7$ & $299 \pm 14.4$ & $600 \pm 51.6$ & $266 \pm 13.4$ & $614 \pm 44.9$ & $259 \pm 29.1$ \\
\hline Hanging frequency (times/day) & $89 \pm 21.1$ & $55 \pm 9.6$ & $90 \pm 16.9$ & $65 \pm 12.6$ & $97 \pm 22.1$ & $66 \pm 8.7$ & $108 \pm 16.6$ & $50 \pm 6.5$ & $99 \pm 7.1$ & $55 \pm 11.1$ \\
\hline Hanging duration (hr/day) & $7.8 \pm 0.30$ & $12.6 \pm 0.29$ & $7.8 \pm 0.30$ & $12.4 \pm 0.30$ & $8.3 \pm 0.33$ & $12.8 \pm 0.33$ & $7.7 \pm 0.31$ & $12.9 \pm 0.24$ & $7.8 \pm 0.29$ & $12.9 \pm 0.29$ \\
\hline Distance travelled ( $\mathrm{m} /$ day) & $39 \pm 2.0$ & $13 \pm 0.5$ & $78 \pm 4.2$ & $27 \pm 0.5$ & $250 \pm 15.8$ & $83 \pm 4.7$ & $408 \pm 37.7$ & $122 \pm 6.9$ & $580 \pm 35.7$ & $157 \pm 6.5$ \\
\hline Feeding rate ( $\mathrm{g} \mathrm{cal} / \mathrm{g} / \mathrm{day})$ & $108.2 \pm 1.80$ & --- & $112.8 \pm 2.36$ & -- & $108.7 \pm 2.36$ & - \pm & $142.7 \pm 1.09$ & -- & $136.9 \pm 0.91$ & -- \\
\hline Absorption rate ( $\mathrm{g} \mathrm{cal} / \mathrm{g} / \mathrm{day})$ & $103.6 \pm 1.65$ & --- & $109.3 \pm 0.71$ & --- & $105.6 \pm 3.00$ & -- & $139.2 \pm 0.92$ & --- & $132.3 \pm 0.92$ & --- \\
\hline Conversion rate $(\mathrm{g} \mathrm{cal} / \mathrm{g} / \mathrm{day})$ & $+19.4 \pm 0.69$ & $-13.0 \pm 0.40$ & $+19.4 \pm 0.69$ & $-12.9 \pm 0.52$ & $+19.9 \pm 0.80$ & $-14.4 \pm 0.72$ & $+22.9 \pm 0.08$ & $-15.8 \pm 0.79$ & $+22.9 \pm 0.35$ & $-17.4 \pm 0.11$ \\
\hline Metabolic rate $(\mathrm{g} \mathrm{cal} / \mathrm{g} /$ day $)$ & $75.6 \pm 1.00$ & $13.0 \pm 0.40$ & $80.0 \pm 0.13$ & $12.9 \pm 0.52$ & $78.2 \pm 0.24$ & $14.4 \pm 0.72$ & $104.7 \pm 0.09$ & $15.8 \pm 0.79$ & $98.3 \pm 0.09$ & $17.4 \pm 0.11$ \\
\hline Metabolic rate $\left(\mathrm{ml} \mathrm{O}_{2} / \mathrm{g} / \mathrm{hr}\right)$ & $0.66 \pm 0.01$ & $0.11 \pm 0.01$ & $0.71 \pm 0.01$ & $0.11 \pm 0.01$ & $0.67 \pm 0.02$ & $0.13 \pm 0.01$ & $0.91 \pm 0.02$ & $0.14 \pm 0.01$ & $0.86 \pm 0.01$ & $0.15 \pm 0.01$ \\
\hline Absorption efficiency $(\%)$ & $95.7 \pm 0.92$ & --- & $96.9 \pm 0.85$ & --- & $97.1 \pm 2.39$ & --- & $97.5 \pm 1.00$ & --- & $96.7 \pm 1.00$ & --- \\
\hline Conversion efficiency $\left(\mathrm{K}_{2}\right)(\%)$ & $18.7 \pm 0.86$ & --- & $17.7 \pm 0.45$ & --- & $18.9 \pm 0.41$ & --- & $16.5 \pm 0.06$ & ---- & $17.3 \pm 0.35$ & --- \\
\hline
\end{tabular}

Table VI. Effects of feeding, starvation and aquarium depth on different metabolic parameters in Ophiocephalus striatus (41.1 $\pm 1.36 \mathrm{~g})$. Each value represents the average performance of 3 to 6 individuals observed for a period of 35 days at $27^{\circ} \mathrm{C}$.

Depth of water $(\mathrm{cm})$

\begin{tabular}{|c|c|c|c|c|c|c|c|c|}
\hline \multirow{2}{*}{ Parameters } & \multicolumn{2}{|r|}{10} & \multicolumn{2}{|r|}{31} & \multicolumn{2}{|r|}{50} & \multicolumn{2}{|r|}{70} \\
\hline & Fed & Starved & Fed & Starved & Fed & Starved & Fed & Starved \\
\hline Number of surfacing/day & $480 \pm 19.4$ & $278 \pm 14.4$ & $512 \pm 18.0$ & $286 \pm 7.0$ & $569 \pm 28.1$ & $274 \pm 7.7$ & $576 \pm 33.6$ & $269 \pm 7.7$ \\
\hline Hanging frequency (times/day) & $78 \pm 10.4$ & $45 \pm 8.1$ & $87 \pm 10.1$ & $46 \pm 10.2$ & $79 \pm 0.1$ & $55 \pm 8.4$ & $78 \pm 16.3$ & $55 \pm 11.2$ \\
\hline Hanging duration (hr/day) & $8.8 \pm 0.38$ & $12.5 \pm 0.24$ & $8.8 \pm 0.39$ & $12.8 \pm 0.32$ & $8.8 \pm 3.1$ & $12.8 \pm 0.30$ & $8.8 \pm 0.38$ & $12.8 \pm 0.36$ \\
\hline Distance travelled (m/day) & $61 \pm 2.7$ & $21 \pm 0.9$ & $194 \pm 7.0$ & $80 \pm 2.2$ & $370 \pm 19.7$ & $133 \pm 9.7$ & $507 \pm 31.9$ & $187 \pm 6.0$ \\
\hline Feeding rate ( $\mathrm{g} \mathrm{cal} / \mathrm{g} /$ day $)$ & $106.4 \pm 3.67$ & --- & $108.2 \pm 0.68$ & --- & $121.4 \pm 1.50$ & --- & $118.2 \pm 2.72$ & --- \\
\hline Absorption rate $(\mathrm{g} \mathrm{cal} / \mathrm{g} / \mathrm{ady})$ & $103.5 \pm 3.03$ & --- & $104.9 \pm 0.76$ & --- & $118.1 \pm 1.01$ & --- & $107.9 \pm 2.77$ & --- \\
\hline Conversion rate ( $\mathrm{g} \mathrm{cal} / \mathrm{g} /$ day $)$ & $+18.5 \pm 1.38$ & $-12.0 \pm 1.96$ & $+20.2 \pm 0.69$ & $-12.9 \pm 0.95$ & $+20.3 \pm 0.45$ & $-15.8 \pm 0.81$ & $+19.1 \pm 0.67$ & $-12.9 \pm 0.95$ \\
\hline Metabolic rate ( $\mathrm{g} \mathrm{cal} / \mathrm{g} /$ day) & $76.5 \pm 1.60$ & $12.0 \pm 1.96$ & $76.3 \pm 0.21$ & $12.9 \pm 0.95$ & $88.1 \pm 0.48$ & $15.8 \pm 0.81$ & $80.0 \pm 0.81$ & $12.9 \pm 0.95$ \\
\hline Metabolic rate $\left(\mathrm{ml} \mathrm{O}_{2} / \mathrm{g} / \mathrm{hr}\right)$ & $0.67 \pm 0.01$ & $0.10 \pm 0.02$ & $0.67 \pm 0.01$ & $0.11 \pm 0.01$ & $0.77 \pm 0.02$ & $0.14 \pm 0.01$ & $0.70 \pm 0.02$ & $0.11 \pm 0.01$ \\
\hline Absorption efficiency $(\%)$ & $97.2 \pm 0.15$ & --- & $97.1 \pm 2.12$ & --- & $97.3 \pm 2.17$ & --- & $91.3 \pm 1.96$ & --- \\
\hline Conversion efficiency $\left(\mathrm{K}_{2}\right)(\%)$ & $17.8 \pm 2.31$ & --- & $19.2 \pm 0.63$ & --- & $17.2 \pm 0.81$ & --- & $17.8 \pm 0.72$ & --- \\
\hline
\end{tabular}


striatus tend to convert more efficiently in aquaria containing larger volumes of water.

Body substances converted into metabolic activity by the starving fish increased generally with increasing aquarium depth in the weight classes of 0.75 , I0, 20 and $4 \mathrm{I} \mathrm{g}$ (Fig. 3b; middle panel); the increase in negative conversion rate with increasing aquarium depth became less and less marked in the larger weight classes. Secondly, the level of the negative conversion rate was between 28 and $20 \mathrm{~g} \mathrm{cal} / \mathrm{g} /$ day for the $0.75 \mathrm{~g}$ fish; with increasing body weight, the level decreased to around 20 , I 5 and I 3 $\mathrm{g} \mathrm{cal} / \mathrm{g} /$ day in IO, 20 and $4 \mathrm{I} \mathrm{g}$, respectively.

\section{$\mathrm{O}_{2}$ uptake}

The generalisations made for the feeding and starving fish on conversion as a function of aquarium depth equally hold good for oxygen uptake. In either series, $\mathrm{O}_{2}$ uptake decreased in the following order: $0.75<0$. I $<$ I0 $<20<4$ I g; except for the 0 . I $g$ weight class, $\mathrm{O}_{2}$ uptake increased with increasing aquarium depth; the increases were more marked for the smaller weight classes of the feeding fish in comparison to the larger weight classes and the starving fish. Oxygen uptake of the feeding fish was nearly 6 times higher ( $\mathrm{I} .4 \mathrm{ml} / \mathrm{g}$ live fish/hr) than that $(0.24 \mathrm{ml} / \mathrm{g} / \mathrm{hr}$ ) of the starving ones (Fig. 3a \& b; right panel); in the larger weight classes too such a difference was maintained. $\mathrm{O}_{2}$ uptake was 0.7 and $0 . \mathrm{I} \mathrm{ml} / \mathrm{g} / \mathrm{hr}$ for the feeding and starving fish (4I $\mathrm{g}$ body weight), respectively.

\section{Discussion}

The most remarkable finding of the present study is the shift observed on surfacing activity and food utilisation of
Ophiocephalus striatus from its depth-dependency to volume-dependency when the fish grows over $20 \mathrm{~g}$ body weight. In the o. I g weight class, which is known to have not yet completed the ontogenetic development of the air-breathing organ (Das, 1927) and the regular surfacing behaviour (Vivekanandan, I977b), rate and efficiency of food conversion were significantly higher in deeper aquaria (see Table III) and hence growth of this class is volume-dependent, as deeper aquaria contain larger volumes of water. Therefore, it is recommended that individuals weighing less than $0.75 \mathrm{~g}$, may profitably be cultured in nurseries containing a larger volume of water, those weight classes between 0.75 and $20 \mathrm{~g}$ in shallow nurseries and the larger weight classes in big aquatic systems.

All the indices of behavioural activity as well as food utilisation were significantly dependent on body weight. In Table VII, the appropriate data obtained for different weight classes kept in aquaria of $3 \mathrm{I} \mathrm{cm}$ are presented. The levels of the chosen metabolic indices were calculated from the available data for the appropriate aquarium depths, in which the different chosen weight classes will have to surface 8 times their respective body lengths per surfacing and the values thus obtained are presented in Table VIII. In either analysis, body weight first depresses feeding rate, which is reflected in the decreased rate and efficiency of food conversion.

Calculating the logarithm of gross growth efficiency $\left(\mathrm{K}_{1}\right)$ and ration $(\mathrm{R}=$ feeding rate), or body weight $(\mathrm{W})$ of the Japanese plaice Limanda yokohamae reported by Hatanaka et al. (1956), Paloheimo and Dickie (I966b) found that $\log \mathrm{K}_{1}$ decreases linearly with increasing $\mathrm{R}$, or W. From similar analyses of other available data, Paloheimo \& Dickie (I966b) suggested that conversion efficiency is determined by ration level alone and not by body weight. Similar analyses of the data reported for $O$. stria-

Table VII. Effect of body weight on different metabolic parameters in Ophiocephalus striatus reared in aquarium containing $31 \mathrm{~cm}$ depth of water; each value represents the average performance of 3 to 6 individuals (mean \pm SD) at $27^{\circ} \mathrm{C}$.

\begin{tabular}{llllllll}
\hline $\begin{array}{l}\text { Weight } \\
\text { class } \\
(\mathrm{g})\end{array}$ & $\begin{array}{l}\text { Number of } \\
\text { surfacing } \\
\text { (times/day) }\end{array}$ & $\begin{array}{l}\text { Hanging } \\
\text { duration } \\
\text { (hr/day) }\end{array}$ & $\begin{array}{l}\text { Distance } \\
\text { travelled } \\
(\mathrm{m} / \text { day) }\end{array}$ & $\begin{array}{l}\text { Feeding } \\
\text { rate } \\
(\mathrm{g} \mathrm{cal} / \mathrm{g} / \mathrm{day})\end{array}$ & $\begin{array}{l}\text { Conversion } \\
\text { rate } \\
(\mathrm{g} \mathrm{cal} / \mathrm{g} / \text { day })\end{array}$ & $\begin{array}{l}\text { Metabolic } \\
\text { rate } \\
(\mathrm{ml} \mathrm{O} / \mathrm{g} / \mathrm{hr})\end{array}$ & $\begin{array}{l}\text { Conversion } \\
\text { efficiency } \\
\left(\mathrm{K}_{2}\right)(\%)\end{array}$ \\
\hline 0.1 & $1146 \pm 526$ & $1.0 \pm 0.6$ & $681 \pm 312$ & $289 \pm 12.8$ & $127 \pm 12.0$ & $1.20 \pm 0.13$ & $45 \pm 4.1$ \\
0.75 & $1798 \pm 122$ & $2.5 \pm 0.6$ & $999 \pm 75$ & $216 \pm 6.2$ & $27 \pm 1.5$ & $1.41 \pm 0.07$ & $13 \pm 1.0$ \\
10 & $1046 \pm 76$ & $5.6 \pm 0.1$ & $507 \pm 37$ & $157 \pm 18.5$ & $25 \pm 0.2$ & $0.99 \pm 0.17$ & $16 \pm 2.3$ \\
20 & $624 \pm 37$ & $8.3 \pm 0.3$ & $250 \pm 16$ & $109 \pm 2.4$ & $20 \pm 0.8$ & $0.67 \pm 0.02$ & $19 \pm 0.4$ \\
41 & $512 \pm 18$ & $8.8 \pm 0.4$ & $194 \pm 7$ & $108 \pm 0.7$ & $20 \pm 0.7$ & $0.67 \pm 0.01$ & $19 \pm 0.6$ \\
\hline
\end{tabular}


Table VIII. Effect of body weight on different metabolic parameters in Ophibcephelus striatus reared in aquarium depechs, in

\begin{tabular}{|c|c|c|c|c|c|c|c|c|}
\hline $\begin{array}{l}\text { Body } \\
\text { weight } \\
\text { (g) }\end{array}$ & $\begin{array}{l}\text { Depth of } \\
\text { water } \\
\text { (cm) }\end{array}$ & $\begin{array}{c}\text { Number of } \\
\text { surfacing } \\
\text { (timess/cay) }\end{array}$ & $\begin{array}{l}\text { Hanging } \\
\text { duration } \\
\text { (ins/day) }\end{array}$ & $\begin{array}{l}\text { Distance } \\
\text { travelled } \\
\text { (m/day) }\end{array}$ & $\begin{array}{l}\text { Feeding } \\
\text { rate } \\
\text { (g cal// } \\
\text { g/day) }\end{array}$ & $\begin{array}{c}\text { Conversion } \\
\text { rate } \\
\text { (g/all } \\
\mathrm{g} / \mathrm{day})\end{array}$ & $\begin{array}{c}\text { Metabolic } \\
\text { rate } \\
\left(\mathrm{ml} \mathrm{O}_{3} / \mathrm{g} / \mathrm{ht}\right)\end{array}$ & $\begin{array}{l}\text { Conversion } \\
\text { efficiency } \\
\left(K_{2}\right)(\%)\end{array}$ \\
\hline 0.1 & 10 & 1260 & 1.0 & 250 & 270 & 97 & 1.3 & 37 \\
\hline 0.75 & 20 & 1650 & 2.7 & 300 & 200 & 25 & 1.3 & 13 \\
\hline 10.0 & 40 & 1110 & 5.8 & 690 & 160 & 25 & 1.0 & 16 \\
\hline 20.0 & so & 600 & 7.7 & 400 & 143 & 23 & 0.9 & 17 \\
\hline 41.0 & 70 & 580 & 8.8 & 510 & 118 & 19 & 0.7 & 18 \\
\hline
\end{tabular}

Please read fifth column $4 \mathrm{IO}$ instead of 400 .

tus indicate that the $\mathrm{K}_{1}$ values obtained for the weight class O.I $\mathrm{g}$ remain incomparably high, when $\log \mathrm{K}_{1}$ is related to R (Fig. 4a) or W (Fig. 4b). When the data obtained for the $0.1 \mathrm{~g}$ weight class are ignored, a more or less inverse relationship between $\log \mathrm{K}_{1}$ and $\mathrm{R}$ is obtained,
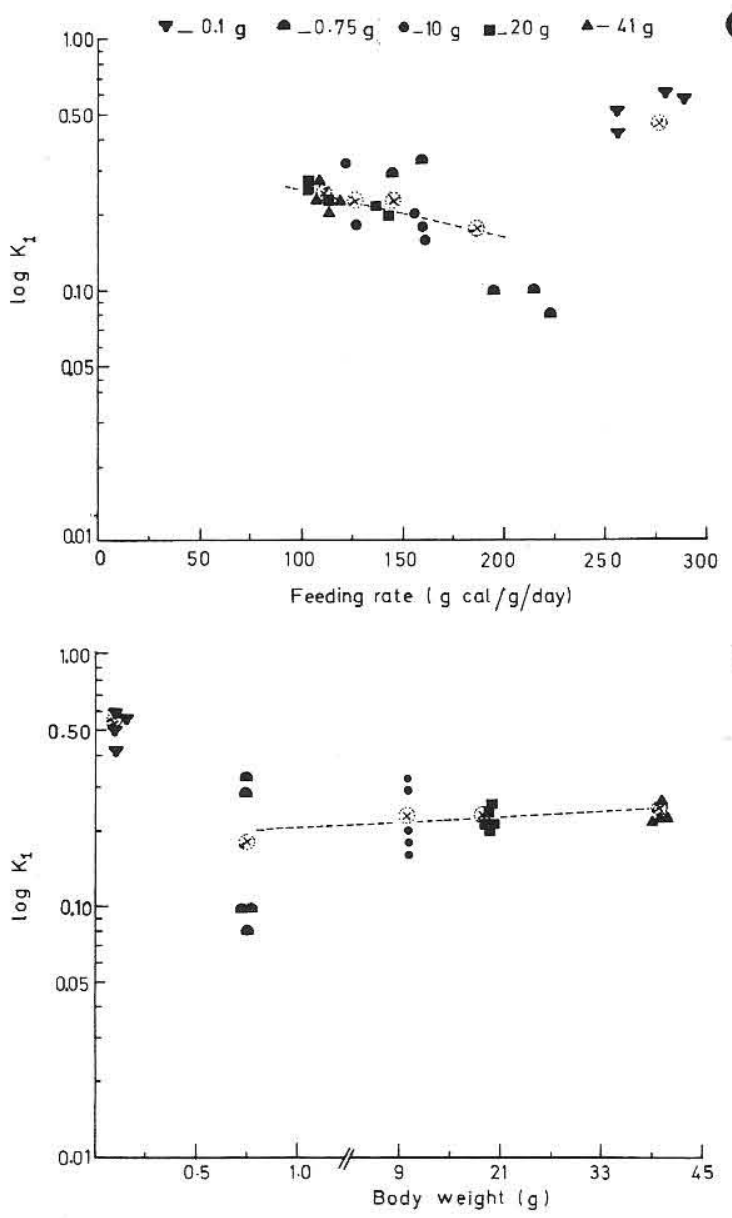

Fig. 4. Relations between I. body weight (W) and log gross conversion efficiency $\left(\mathrm{K}_{1}\right)$ (lower panel), 2. 'rations' $(\mathrm{R})$ and $\log \mathrm{K}_{1}$ (upper panel) of Ophiocephalus striatus. Each value represents the average performance of 3 to 6 individuals; the values for the mean of means obtained for different weight classes exposed to different depths are indicated by $\mathrm{X}$; it is through these values, the straight line relationship is shown.

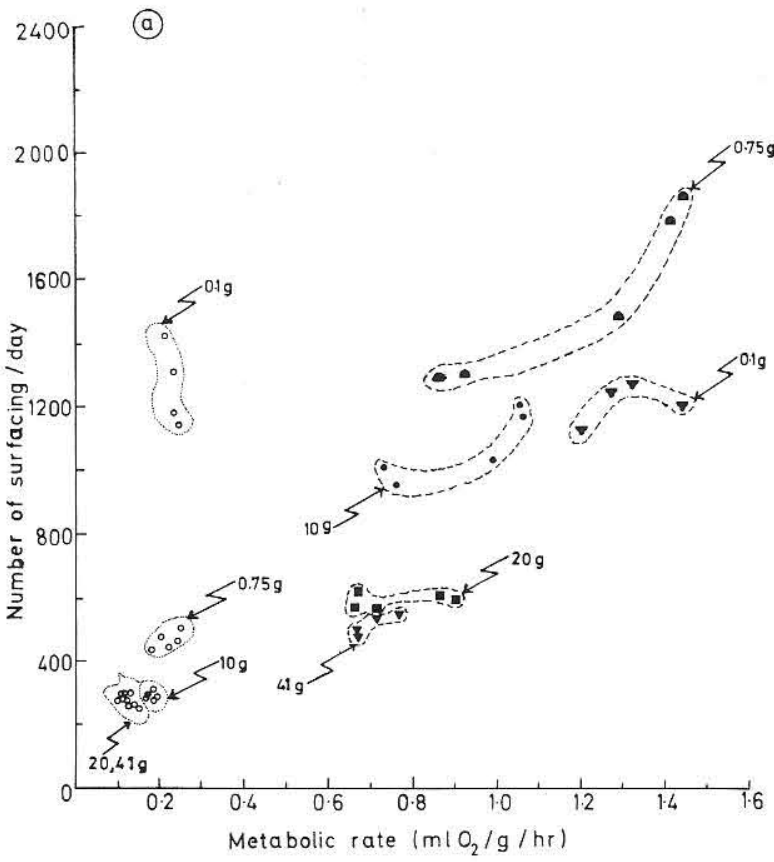

Fig. 5. Metabolic rate as functions of surfacing frequency (panel a), hanging duration (panel b) and distance travelled (panel c) in the fed (closed symbols) and starved (open symbols) Ophiocephalus striatus of different weight classes. For each weight class, 4 to 5 values represent the aquarium depths, at which the fishes were tested.

which recalls the trend obtained for different fishes by Paloheimo \& Dickie (1966b). However, that obtained for $\log \mathrm{K}_{\mathrm{I}}$ and $\mathrm{W}$ is linear and not inverse; in fact, it tends to increase with increasing W. Hence this aspect of theoretical examination of data requires more experimental evidences before any conclusion is made.

As Vivekanandan \& Pandian (I977) showed direct and good correlations between rate of food/fish energy input and oxygen uptake in the feeding and starving $O$. striatus as functions of ration, aquarium depth, $\mathrm{pO}_{2}$, temperature and body weight, the data obtained in the present study on the behavioural activities associated with air-breathing habit-namely surfacing, hanging and swimming-have been correlated with the $\mathrm{O}_{2}$ uptake of different classes of $O$. striatus (Fig. 5). With increasing $\mathrm{O}_{2}$ uptake, the surfacing frequency (Fig. 5a) and swimming activity (Fig. 5c) increased more or less linearly, and the hanging duration (Fig. 5b) decreased. The group weighing 0.I g, which has not fully completed the ontogenetic development of airbreathing habit, (see Vivekanandan, 1977b) remains an exceptional case in terms of surfacing, hanging and swimming activities for obvious reasons. In all panels of 
(b)

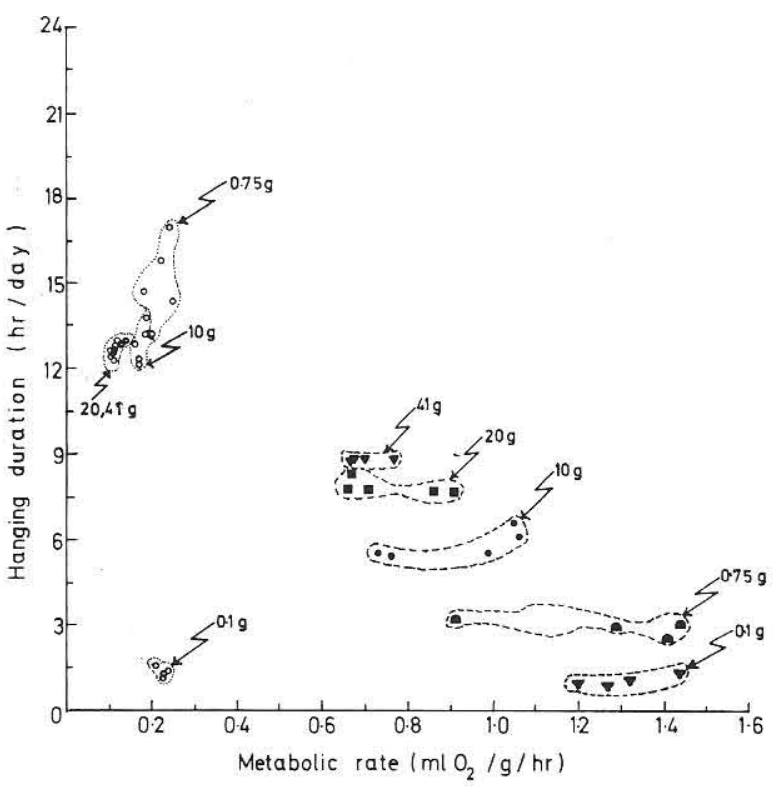

Fig. 5b.

Figure 5, the values obtained for the starving $O$. striatus of different weight classes exposed to different depths of aquaria fall closely to the left corner of the graph and those of the feeding series occupy a greater area on the right side. It is known that any factor tending to alter the feeding rate is immediately followed by a more or less corresponding change in the level of $\mathrm{O}_{2}$ uptake (Smith, 1935; Solomon \& Brafield, 1972; Beamish, 1974; Ponniah and Pandian, 1977). When the data obtained from the previous and present studies on $O$. striatus are analysed, the tested factors like temperature (Vivekanandan \& Pandian, 1977), depth of aquaria (Pandian \& Vivekanandan, 1976), $\mathrm{pO}_{2}$ of water (Vivekanandan, 1977a) and body weight (present study) appear to alter the feeding rate first of all. The altered feeding rate, in turn, elevates or depresses the $\mathrm{O}_{2}$ uptake, which triggers off a corresponding but very complicated series of changes in the levels of behavioural activities, namely surfacing, hanging and swimming. The pathway, through which the effects of these factors influenced O. striatus (Fig. 6) is supported by the following evidences: $\mathrm{I}$. The distance swum was only $45 \mathrm{~m} /$ day by the feeding group reared in $2.5 \mathrm{~cm}$ aquaria, whereas it was as much as $163 \mathrm{~m} /$ day for the starving group kept in aquaria containing $40 \mathrm{~cm}$ of water. If the tested aquarium depth is assumed to have affected (c)

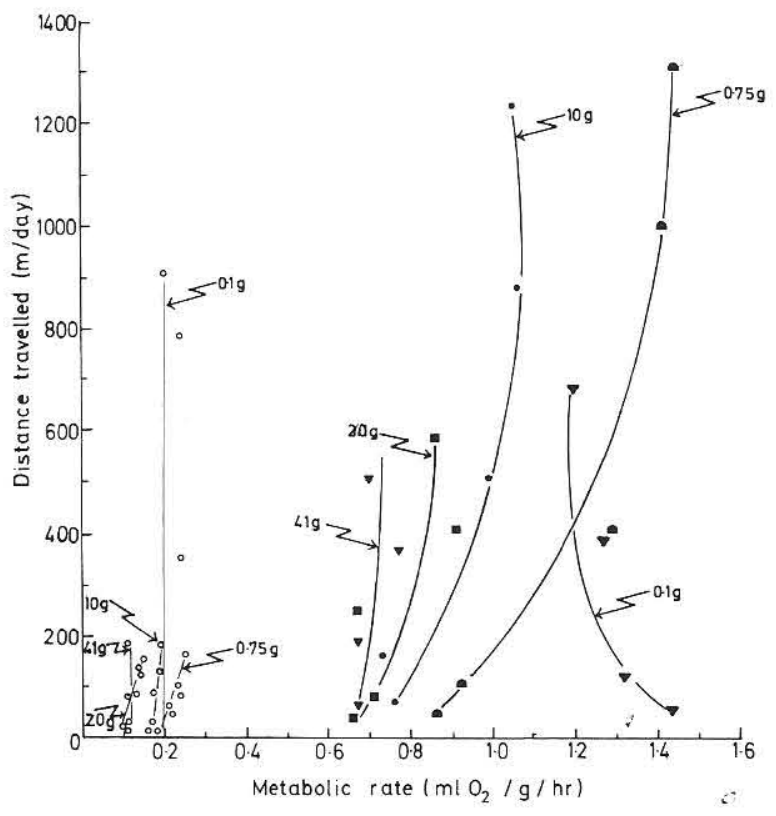

Fig. 5c.

the $\mathrm{O}_{2}$ uptake through swimming activity in the first place, the $\mathrm{O}_{2}$ uptake of the feeding group in the aquarium containing a minimum depth of water $(2.5 \mathrm{~cm})$ need not have been as high as $0.86 \mathrm{ml} / \mathrm{g} / \mathrm{hr}$ and that of the starving group in $40 \mathrm{~cm}$ depth as low as $0.25 \mathrm{ml} / \mathrm{g} / \mathrm{hr}$ (Table II). 2. If a factor like temperature is considered to affect the $\mathrm{O}_{2}$ uptake via surfacing activity, then the surfacing activity need not have decreased to around I,200 times/day at

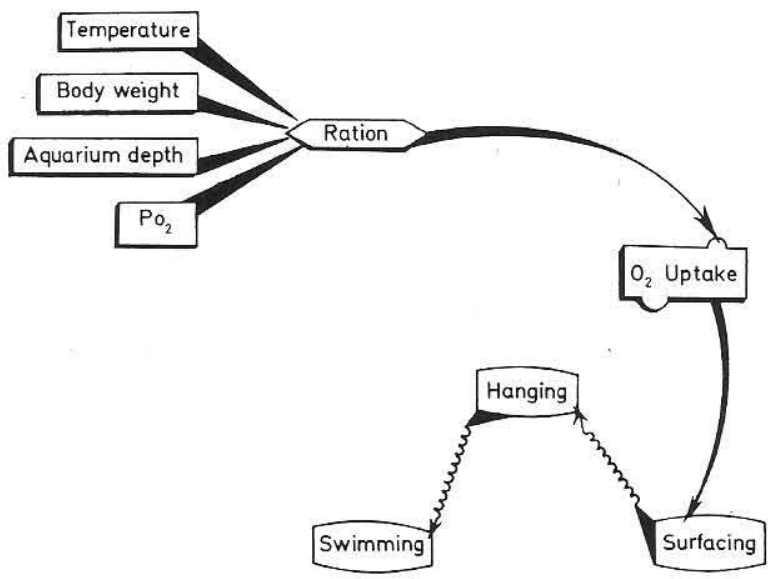

Fig. 6. A proposed scheme of pathway through which endogenous and environmental factors influence the different metabolic parameters studied in Ophiocephalus striatus. 
$37^{\circ} \mathrm{C}$, (Fig. I in Vivekanandan \& Pandian, 1977), when the $\mathrm{O}_{2}$ uptake remained more or less around $\mathrm{I} .2 \mathrm{ml} / \mathrm{g} / \mathrm{hr}$ (Fig. 7 in Vivekanandan \& Pandian, 1977) at 27, 32 and $37^{\circ} \mathrm{C}$, or the feeding rate need not have remained around $200 \mathrm{~g} \mathrm{cal} / \mathrm{g} /$ day (Fig. 5b in Vivekanandan \& Pandian, I977) at these temperatures, and 3. Conversely, when the feeding rate was experimentally controlled, the reduced rations immediately depressed $\mathrm{O}_{2}$ uptake and surfacing activity (see also Vivekanandan, 1976); the swimming activity was proportionately very much reduced through prolonged hanging duration.

\section{References}

Beamish, F. W. H. I974. Apparent specific dynamic action of largemouth bass Micropterus salmoides. J. Fish. Res. Bd. Canada 31: $1763-1769$.

Brown, M. E. 1957. Experimental studies on growth, Vol. I, pp. $36 \mathrm{I}-400$ in M. E. Brown (Editor). The Physiology of Fishes. Academic Press, New York.

Das, B. K. 1927. The bionomics of certain air-breathing fishes of India, together with an account of the development of their airbreathing organs. Phil. Trans. Roy. Soc. London 2 I6: 183-2I9.

De Roth, G. C. 1973. Effects of temperature and light on airbreathing behaviour of the spotted gar Lepisosteus oculatus. Ohio J. Sci. 73: 34-4I.

Engelmann, F. 1966. Energetics, terrestrial field studies and animal productivity. Adv. ecol. Res. 3: 73-I I5.

Gerking, S. D. 1955. Influence of rate of feeding and body composition on protein metabolism of bluegill sunfish. Physiol. Zool. 28: 267-282.

Gerking, S. D. I971. Influence of rate of feeding and body weight on protein metabolism of bluegill sunfish. Physiol. Zool. 44: 9-19.

Hatanaka, M., Kosaka, M. \& Sato, Y. 1956. Growth and food consumption of plaice. I. Limanda yokohamae (Gowther). Tohoku J. Agri. Res. I: I5I-I62.

Maynard, A. L. \& Loosli, K. J. 1962. Animal Nutrition. p. 533. McGraw-Hill, New York.

Menzel, D. W. 1960. Utilisation of food by a Bermuda reef fish, Epinephelus guttatus. J. Cons. Perm. Int. Explor. Mar. 25: 216-222.

Paloheimo, J. E. \& Dickie, L. M. 1966a. Food and growth of fishes. II. Effects of food and temperature on the relation between metabolism and body weight. J. Fish. Res. Bd. Canada 23: 869-908.

Paloheimo, J. E. \& Dickie, L. M. I966b. Food and growth of fishes. III. Relations among food, body size and growth efficiency. J. Fish. Res. Bd. Canada 23: I 209-I 248.

Pandian, T. J. 1967. Intake, digestion, absorption and conversion of food in the fishes Megalops cyprinoides and Ophiocephalus striatus. Mar. Biol. I: I6-32.

Pandian, T. J. \& Vivekanandan, E. 1976. Effects of feeding and starvation on growth and swimming activity in an obligatory air-breathing fish. Hydrobiologia 49: 33-39.

Petrusewicz, K. \& MacFadyen, A. 1970. Production of terrestrial animals. IBP Handbook, No. 13, P. 190, Blackwell Scientific Publications, Oxford.

Ponniah, A. G. \& Pandian, T. J. 1977. Surfacing activity and food utilisation in the air-breathing fish Polyacanthus cupanus exposed to constant $\mathrm{pO}_{2}$. Hydrobiologia (in press).

Ricker, W. E. 1946. Production and utilisation of fish populations. Ecol. Monogr. 16: 373-391.

Smith, H. W. 1935. The metabolism of lungfish. II. Effects of feeding on meat in the metabolic rate. J. cell. comp. Physiol. 6: $335-349$.

Solomon, D. J. \& Brafield, A. D. 1972. The energetics of feeding, metabolism and growth of perch (Perca fluviatilis L.). J. Anim. Ecol. 41: 699-718.

Vivekanandan, E. 1976. Effects of feeding rate on swimming activity and growth in the tropical fish Ophiocephalus striatus. J. Fish Biol. 8: 32 I-330.

Vivekanandan, E. 1977a. Effects of the $\mathrm{pO}_{2}$ on swimming activity and food utilisation in Ophiocephalus striatus. Hydrobiologia 52: $165-170$.

Vivekanandan, E. I977b. Ontogenetic development of surfacing behaviour in the obligatory air-breathing fish Channa (Ophiocephalus) striatus. Physiol. Behav. (in press).

Vivekanandan, E. \& Pandian, T. J. 1977. Surfacing activity and food utilisation in a tropical air-breathing fish exposed to different temperatures. Hydrobiologia (in press).

Warren, C. E. \& Davis, G. E. 1967. Laboratory studies in the feeding, bioenergetics and growth of fish. P. 175-214 in S. D. Gerking (Editor). The biological basis of freshwater fish production. Blackwell Scientific Publications, Oxford.

Weatherley, A. H. 1972. Growth and Ecology of fish production. p. 293. McGraw-Hill, New York. 